\title{
Nem criptoteologia nem reducionismo sociológico: contribuições para o debate epistemológico das Ciências da Religião no Brasil
}

\author{
Arnaldo Érico Huff Júnior* \\ Carlos Eduardo Brandão Calvani**
}

\section{Resumo}

Construiu-se ao longo das últimas décadas um conflito teórico-político interno às Ciências da Religião no Brasil. De um lado, estão as abordagens próximas à filosofia, à teologia e à fenomenologia, onde autores como Otto, Tillich e Eliade são referências. De outro, as abordagens em perspectiva social científica, quando autores como Durkheim, Weber e Bourdieu constituem o parâmetro. Esta polarização, ao passo que, acirra os ânimos, ao mesmo tempo constiui um panorama pouco auspicioso para a consolidação da área. Fluem, de ambos os lados, acusações de "criptoteologia" e de "reducionismo sociológico". A tendência é a de um encastelamento disciplinar e ideológico que não possibilita nem horizontes dialogais e nem a construção identitária das Ciências da Religião no contexto das demais humanidades. Uma possibilidade de superação de tal polarização consiste no entendimento da disciplina como composta por dois momentos complementares, um sistemático e outro histórico. Trata-se de uma compreensão que surge nos inícios da Ciência da Religião europeia e que pode lançar luzes no atual debate brasileiro. Sustentando tal concepção, uma atitude empática ante o fenômeno religioso continua sendo necessária por parte dos pesquisadores.

Palavras-chave: Ciências da Religião, Epistemologia, Identidade

* ORCID iD https://orcid.org/0000-0002-5313-9749. UFJF. Bacharel em Teologia. Doutor em Ciência da Religião (UFJF) e professor da UFJF. huffjr_@hotmail.com .

** ORCID iD https://orcid.org/0000-0001-5646-3360. UFS. Bacharel em teologia, doutor em ciências da religião (UMESP), professor da UFS. cecalvani@hotmail.com . 


\title{
Neither cryptotheology nor sociological reductionism: contributions to the epistemological debate of the Sciences of Religion in Brazil
}

\begin{abstract}
A theoretical-political conflict within the Sciences of Religion in Brazil has been built over the past few decades. On the one hand, there are approaches close to philosophy, theology and phenomenology, where authors such as Otto, Tillich and Eliade are references. On the other hand, approaches in a social scientific perspective, when authors such as Durkheim, Weber and Bourdieu constitute the parameter. This polarization, while heightens spirits, at the same time, is an inauspicious panorama for the consolidation of the area. Accusations of "cryptotheology" and "sociological reductionism" flow from both sides. The tendency is for a disciplinary and ideological shutdown that allows neither dialogical horizons nor the identity construction of the Sciences of Religion among the other human sciences. One possibility to overcome such polarization consists in understanding the discipline as being composed of two complementary moments, one systematic and the other historical. It is an understanding that arises at the beginning of the European Science of Religion and can shed light on the current Brazilian debate. Supporting this conception, an empathetic attitude towards the religious phenomenon remains necessary on the part of the researchers.
\end{abstract}

Keywords: Science of Religion, epistemology, identity

\section{Ni criptoteología ni reduccionismo sociológico: contribuciones al debate epistemológico de las ciencias de la religión en Brasil}

\section{Resumen}

En las últimas décadas, se ha construido un conflicto teórico-político dentro de las Ciencias de la Religión en Brasil. Por un lado, hay enfoques cercanos a la filosofía, la teología y la fenomenología, donde autores como Otto, Tillich y Eliade son referentes. Por otro lado, enfoques desde una perspectiva científico-social, cuando autores como Durkheim, Weber y Bourdieu constituyen el parámetro. Esta polarización, al paso que agita los ánimos, constituye al mismo tiempo un panorama desfavorable para la consolidación de la área. Las acusaciones de "criptoteología" y "reduccionismo sociológico" fluyen de ambos lados. La tendencia es hacia un atrincheramiento disciplinar e ideológico que no permite horizontes dialógicos ni la construcción identitaria de las Ciencias de la Religión en el contexto de las otras humanidades. Una posibilidad de superar esta polarización es la comprensión de la disciplina como compuesta de dos momentos complementarios, uno sistemático y otro histórico. Es un entendimiento que surge de los inicios de la Ciencia Europea de la Religión y que puede arrojar luz sobre el actual debate brasileño. Apoyando esta concepción, sigue siendo necesaria una actitud empática hacia el fenómeno religioso por parte de los investigadores.

Palabras clave: ciencia de la religión, epistemología, identidad. 
Nem criptoteologia nem reducionismo sociológico: 361 contribuições para o debate epistemológico das Ciências da Religião no Brasil

\section{Introdução}

Os debates recentes em torno da epistemologia das Ciências da Religião são bastante frutíferos e enriquecedores. Porém, em tempos de polarizações exacerbadas, correm o risco de criar fronteiras e trincheiras nas quais se encastelam opositores que se esquecem de que são colegas e pares, e que passam a gastar mais energias no esforço por desqualificar aliados do que propriamente na tentativa de compreender nosso objeto de estudo. O presente texto reconhece que tais debates não são apenas teóricos, mas também políticos e se oferece como uma contribuição adicional ao esclarecimento de certos pressupostos que norteiam nosso trabalho. Após um breve mapeamento sobre a atual organização epistemológica das Ciências da Religião no Brasil e sua "árvore do conhecimento", o texto oferece subsídios para se compreender o lugar da teologia e da fenomenologia da religião (ou empatia estruturada) nesse trabalho comum e colegiado.

\section{A organização político-epistemológica das Ciências da Religião no Brasil: uma casa e muitos quartos}

Há um entendimento clássico acerca da organização disciplinar das Ciências da Religião (CsR), partilhado desde seus primeiros dias na Europa, que compreende a disciplina a partir de dois momentos complementares, um histórico (longitudinal) e um sistemático (transversal). Tal formulação aparece de modo consistente, em 1924, elaborada por Joachim Wach, na obra "Ciência da religião: prolegômenos para seus fundamentos teórico-científicos”" Nas palavras do autor:

O assunto da história das religiões é a multiplicidade de religiões empiricamente dadas. Seu objetivo é estudá-las, entendê-las e retratá-las. Fazse isso de duas maneiras: "longitudinalmente no tempo" (diacronicamente) e em "cortes transversais" (sincronicamente), ou seja, de acordo com o seu desenvolvimento (Entwicklung) e de acordo com o seu ser (Sein). Assim, a

\footnotetext{
O texto foi originalmente publicado em alemão como "Religionswissenschaft: Prolegomena zu ibrer wissenschaftstheoretischen Grundlegung" e tem tradução para o inglês com o título "Introduction to the History of Religions". Infelizmente, de Wach, tem-se em português apenas o texto intitulado "Sociologia da religião", o que pode dar uma impressão limitada da obra do autor. Além dos textos mencionados, Wach tem outras importantes obras de cunho teórico-metodológico e um livro sobre a história da hermenêutica no século dezenove, "Das Verstehen: Grundzüge einer Geschichte der hermeneutischen Theorie im 19. Jabrbundert" (3 vols, 1926-1933) (A compreensão: elementos para uma história da teoria hermenêutica no século XIX).
} 
tarefa da história geral das religiões se divide em uma investigação histórica e uma sistemática das religiões (WACH, 1988, p. 19). ${ }^{2}$

Vale lembrar que o que Wach, entre outros, chamava por vezes de "história das religiões" é o que hoje no Brasil chamamos de "Ciências da Religião". O entendimento de Wach acerca da disciplina em dois momentos foi assumida por diversos outros autores, como Eliade, Kitagawa e Kristensen, por exemplo. ${ }^{3}$

No caso brasileiro, todavia, a organização da disciplina, a partir dos anos 1970, se deu de outra maneira. Como bem entendeu Eduardo Gross (2012), através da afluência da Teologia da Libertação no nascimento de nossas Ciências da Religião, houve uma identificação estreita da disciplina com a sociologia, principalmente. A entrada se deu através da mediação socioanalítica marxista, adotada pelos teólogos da libertação que migraram, por motivos diversos, para a nascente área acadêmica das Ciências da Religião, que prometia uma liberdade maior em relação às amarras eclesiásticas. A academia, por sua vez, acolheu bem a Teologia da Libertação, com sua aspiração por justiça e transformação social, o que emprestou maior legitimidade acadêmica à Teologia e, por conseguinte, às Ciências da Religião. Tratava-se, afinal, de algo diferente do tradicional dogmatismo religioso da Teologia eclesiástica. Marx, por seu turno, fornecia o código compartilhado para tal interação e tais interesses entre a Teologia da Libertação e as outras humanidades.

Com o tempo e o estabelecimento das abordagens culturalistas nas ciências humanas, no contexto do que se chamou de virada linguística, o privilégio da abordagem sociológica clássica nas Ciências da religião foi

2 "The subject matter of the history of religions is the multiplicity of empirically given religions. Its aims are to study them, to understand them, and to portray them. It does so in two ways: 'lengthwise in time' (diachronically) and in 'cross-sections' (synchronically), that is, according to their development (Entwicklung) and according to their being (Sein). Thus, the task of the general history of religions divides into a historical and a systematic investigation of religions" (WACH, 1988, p. 19).

3 P. ex.: "Entende-se geralmente por "história das religiões" ou "religião comparativa" o estudo integral das realidades religiosas, quer dizer, as manifestações históricas de um tipo particular de "religião" (tribal, étnica, supranacional) bem como as estruturas específicas da vida religiosa (formas divinas, concepções da alma, mitos, rituais, etc.; instituições, etc.; tipologia das experiências religiosas, etc.). Estas precisões preliminares não se destinam de modo algum a circunscrever o campo ou a definir os métodos da história das religiões" (ELIADE, 1989, p. 70). Ver tb. Frederico PIEPER (2019, p. 811) 
Nem criptoteologia nem reducionismo sociológico: 363 contribuições para o debate epistemológico das Ciências da Religião no Brasil

se deslocando para o campo de perspectivas antropológicas e relativistas. Nesse momento, o campo das CsR passou a abrigar, portanto, a presença de sociólogos, antropólogos e de outros praticantes da perspectiva sócioculturalista (muitos advindos de experiências de militância eclesiástica na juventude), além de teólogos - dentre estes alguns inclusive assumindo mais abertamente a perspectiva e a identidade profissional das ciências sociais, a fim de se distanciar dos antigos laços eclesiásticos.

Aos poucos outras áreas acadêmicas foram também se acomodando nas CsR, com a chegada de historiadores, psicólogos (minoritariamente) e também de alguns filósofos. Como a formação pós-graduada em CsR era recente e praticamente não havia cursos de graduação, ${ }^{4}$ durante muitos anos aqueles que labutavam nas CsR advinham em sua maioria de outras áreas acadêmicas. Daí, também, que a formulação do nome da área como Ciências da Religião, no plural, tenha se mantido até hoje, assegurando um espaço confortável para todos, cada qual em sua disciplina.

Marcelo Camurça assumiu uma sistematização da disciplina nessa ótica, da seguinte maneira:

Considero que o campo da(s) ciência(s) da religião deva estar sintonizado com os debates, impasses e avanços teórico-metodológicos que estão acontecendo nas respectivas instâncias de cada ciência humana e social, da qual a religião é junto com outras, mais uma subárea; [...] a forma pluralizada como perspectiva acadêmica conduz as disciplinas a se organizarem em um "campo disciplinar", que como tal, possui uma "estrutura aberta e dinâmica" [citando Prandi e Filoramo] [...] considero que é somente por meio de cada abordagem particular nas suas pretensões e limitações - que esse abstrato crucial pode ser conhecido (CAMURÇA, 2001, p. 215-216; grifos no original).

A tônica aqui é a seguinte: para que haja interdisciplinaridade, é preciso haver disciplinaridade. Partindo, então, de entendimentos análogos aos de Camurça, estabeleceu-se hegemonicamente no Brasil uma compreensão das Ciências da religião como um local de convergência de áreas acadêmicas bem estabelecidas no campo universitário das humanidades, letras e artes, e que contêm subdisciplinas com foco em religião. Pode-se pensar em um modelo esquemático assim organizado:

4 Em "Aspectos históricos e epistemológicos da Ciência da Religião no Brasil: Um estudo de caso" (PIEPER, 2018), Frederico Pieper analisou a experiência singular do curso de graduação em Ciência da Religião na UFJF, que teve início nos 1970, foi fechado ao final daquela década e retomou suas atividades em 2011. 


\section{CIÊNCIAS DA RELIGIÃO}

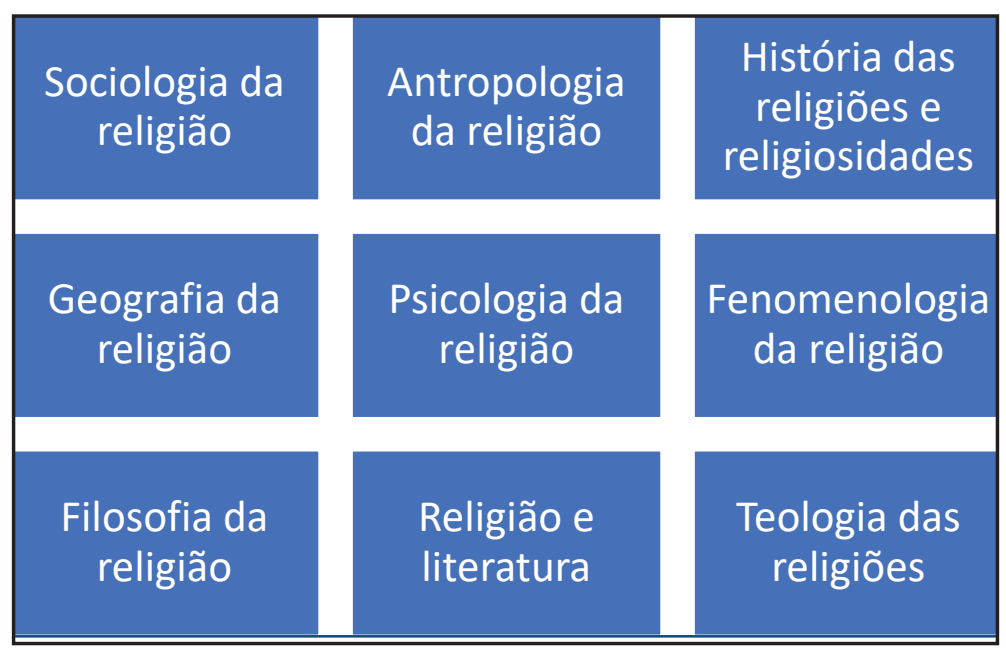

Vai também nesse sentido uma metáfora que aparece aqui e ali em debates e eventos: "As Ciências da religião constituem uma área acadêmica que funciona como uma casa com vários quartos, cada um independente do outro. Volta e meia, porém, os moradores se encontram na sala ou na cozinha para uma conversa amigável e para contar histórias e trocar experiências."

A metáfora é interessante. A prática acadêmica cotidiana, todavia, tem sido outra: a de um enclausuramento nos cânones disciplinares dos quais os pesquisadores são originários. À medida em que o quadro de graduados em Ciências da Religião (licenciados e bacharéis) aumentar, essa situação tende a se alterar, mas por enquanto, especialmente no nível da pesquisa pósgraduada, o que se dá é que cada pesquisador ou estudante permanece no seu próprio espaço da casa, com as portas fechadas, e uns não sabem o que se passa nos quartos dos outros. Nesse caso, cada quarto tem cama, cozinha, banheiro, televisão, internet e saída independente. De fato, os moradores, de vez em quando, se encontram na cozinha para um cafezinho ou um lanche, mas em geral são raros os que, por deferência e coleguismo, abrem as portas de seus quartos e convidam os colegas dos outros quartos para entrar, verificar a biblioteca e conviver com maior proximidade e transparência. A suposta interdisciplinaridade, na maior parte do tempo, não passa de um conjunto de diferentes perspectivas acerca de um mesmo fenômeno, que quando não são abertamente conflitivas, apenas se tocam eventualmente. 
Nem criptoteologia nem reducionismo sociológico: 365 contribuições para o debate epistemológico das Ciências da Religião no Brasil

Cabe aos estudantes e leitores fazerem as suas próprias sínteses. Não se trata, portanto, o mais das vezes, de uma interdisciplinaridade orgânica, e não parece haver um diálogo programático.

\section{Estranhos moradores na casa comum: Fenomenologia e Teologia em questionamento}

As Ciências da Religião, assim compreendidas, com a inclusão de outras perspectivas além da sociológica, acabaram reproduzindo na casa uma antiga cisão. Trata-se da ruptura entre uma concepção substantiva e uma funcional da religião. Ao passo que a visão substantiva entende a religião de forma não-derivada, como uma essência, a visão funcional a percebe como derivada, como um produto social, cultural, econômico, político, etc. O fato é que, do lado da visão substantiva, estão principalmente filósofos, teólogos e simpatizantes da Fenomenologia da Religião; enquanto entre os partidários da visão funcional encontram-se principalmente cientistas sociais, historiadores culturais e adeptos das teorias sociais e culturais da religião. Tais fronteiras podem, eventualmente, aparecer mais ou menos borradas. Esse conflito não é especificamente nacional e tem precedência em debates europeus e estadunidenses.

No Brasil, a tensão se acirrou nos inícios dos anos 2000. Na verdade, o suprarreferido texto de Marcelo Camurça já fez parte do delineamento inicial desse conflito, que é teórico e também político. O texto compõe o livro organizado por Faustino Teixeira, "A(s) ciência(s) da religião no Brasil", que carrega o revelador subtítulo: "Afirmação de uma área acadêmica". O livro foi o resultado de um seminário acontecido em 2000, em Juiz de Fora, que teve o objetivo de reunir pesquisadores de programas de pós-graduação recomendados pela Capes a fim de "trabalhar a questão da afirmação desta área no Brasil, a sua pertinência e os seus desafios" (TEIXEIRA, 2001, p. 3). Passados, porém, mais de vinte anos, mesmo que o estabelecimento da área em termos político-acadêmicos pareça ser já bastante consistente, ${ }^{5}$ não há acordos claros acerca da fundamentação epistemológica das CsR. O caso, ao que parece, é que a disciplina ou área continua nesse caminho truncado,

\footnotetext{
5 Em 2000, os programas de pós-graduação recomendados em CsR eram apenas os da UMESP, PUC-SP e UFJF. Atualmente, existem também programas na PUC-Minas, PUCGO, PUC-Campinas, Faculdade Unida de Vitória, Unicap, UFPB, UFS e UEPA. A área, portanto, nesse tempo, quase quadriplicou seu tamanho e tornou-se independente em relação à Filosofia.
} 
discutindo epistemologia numa "sinuca de bico", onde antigos fantasmas continuam assombrando.

Vamos por um momento aos argumentos em questão, iniciando pelo de Frank Usarski (2001, p. 81-82), em relação à experiência na Alemanha. Usarski indica que o problema não é apenas dos brasileiros:

[...] pensadores como Durkheim e Freud conceberam religião em geral como produto humano. Abordagens deste tipo têm em comum o fato de considerar a religião uma variável dependente, destituída de uma substância própria e completamente explicável com referência a fatores não-religiosos.

Em tensão contra esta corrente reducionista na tradição iluminista, uma segunda linha ideológica, isto é, o Romanticismo tornou-se visível no contexto da ciência da religião, quando Schleiermacher (1768-1834) localizou os fundamentos da religião no sentimento. Na tradição teórica correspondente, incluindo pensadores como Nathan Söderblom, Rudolf Otto, Joachim Wach, Gerardus v.d. Leeuw, Friedrich Heiler, Gustav Mesching ou Günter Lanczkowski, a religião é vista como uma constante antropológica, em seus aspectos sutis mais básicos do que a mente racional e independentes de qualquer manifestação social. Desta maneira a linha fenomenológica mostra-se como um modelo contra o reducionismo e seu foco oposto.

Alguns anos mais tarde, Usarski (2006, p. 31) relembraria, ainda, a pecha dos simpatizantes da Fenomenologia da Religião na Alemanha, sobre os quais se dizia sofrerem de numinose. O termo faz referência à categoria numinoso, utilizada por Otto (2007) para denotar a experiência do sagrado. Segundo Usarski, no Brasil, também o uso indiscriminado do termo sagrado revela uma distorção semelhante e acarreta perigo. O ponto central do argumento me parece ser a crítica ao traço "criptoteológico" da Fenomenologia da Religião:

[...] os críticos à Fenomenologia da Religião chamam a atenção para a estrutura semântica análoga das frases "o sagrado existe" e "Deus existe" e salientam que, nas construções semânticas de autores como Söderblom e Otto, o termo sagrado surge em lugares onde, em obras explicitamente teológicas, se encontraria a palavra "Deus" (Usarski, 2006, p. 40-41).

A Fenomenologia da Religião, nesse sentido, enquanto Teologia disfarçada, não teria cientificidade suficiente para ser incorporada na academia por parte das CsR. Não é consenso, todavia, que afirmações críticas dessa natureza sejam justas para com todos os fenomenólogos e simpatizantes 

contribuiçoes para o debate epistemológico das Ciências da Religião no Brasil

da Fenomenologia da Religião bem como para muitos teólogos. ${ }^{6}$ Do que se depreende da leitura de Eliade, por exemplo, não há motivos para acusá-lo de partir do pressuposto da "existência" de Deus. Menos ainda deve-se concordar com a visão da Teologia como uma disciplina apenas sobrenaturalista. Seria difícil, nesse sentido, argumentar que teólogos advindos da tradição inaugurada por Schleiermacher, como Paul Tillich, por exemplo, ou o nosso Rubem Alves, não possam ser incorporados aos referenciais das CsR em função de uma metafísica sobrenaturalista. Neles, o aspecto ontológico da religião aparece sempre vinculado à sua contraparte históricocultural. "Deus", dizia Tillich (1996, p. 33), "é um símbolo para Deus", atestando sua predileção pela esfera do sentido e pela religião como fenômeno humano simultaneamente ontológico e existencial. Vale lembrar que Tillich sempre rejeitou a afirmação de qualquer realidade por trás ou para além da realidade empírica. Nessa perspectiva, o que é essencial, ou sagrado, o que constitui o homo religiosus, é a experiência humana de sentido último (ou de validade suprema), e não um universo de seres espirituais. ${ }^{7}$

6 Ademais, a Fenomenologia da Religião não pode ser pensada como um bloco unívoco. Carl Bleeker, dispõe ao menos três tipos de estudos fenomenológicos: “(1) a escola descritiva, que se propõe a uma sistematização dos fenômenos religiosos; (2) a escola tipológica, que tem como objetivo pesquisar diferentes tipos de religião; (3) a escola fenomenológica em sentido estrito, que faz questionamentos sobre a essência, o sentido e a estrutura do fenômeno religioso" (Apud OLIVEIRA, 2003, p. 45).

7 O interesse de Eliade voltava-se para o sagrado, bem como para o profano, enquanto experiência, algo que fundamenta a dimensão existencial humana: "O sagrado e o profano constituem duas modalidades de ser no Mundo, duas situações existenciais assumidas pelo homem ao longo da sua história" (ELIADE, 1992, p. 18). No caso de Tillich, seu entendimento do Incondicionado, por exemplo, diz respeito ao elemento responsável pelo caráter propriamente religioso da experiência, sublinhando que "não se trata de um ser, mas de uma qualidade" (TILLICH, 1992, p. 63), ou seja, a qualidade que torna religiosa a experiência religiosa. Rubem Alves, por sua vez, compreendia a religião no horizonte da ampliação dos limites do real, a presença de uma ausência que relembra o paraíso perdido e instaura a esperança. Assim afirmou Alves em um texto sobre a morte de Deus: "aqui está o curioso da experiência. Não tendo mais nas mãos os porquês que justificavam a sua existência, gritamos um apesar de e com ele nos agarramos à existência com uma paixão infinita. [...] revela-se aqui uma dimensão transcendente da existência. Só é possível ter coragem porque o homem, nas suas profundezas, é uma combinação de mágico, criança e sonhador, que proclama, contrariamente a tudo o que a ciência tem dito, que os limites do possível são mais amplos que os limites do real" (ALVES, 1984, p. 81-82). O que Eliade, Tillich e Alves têm em comum é justamente a visada por sobre a religião como fenômeno humano, sem nenhum tipo de pressuposto sobrenaturalista. Na verdade, nas três concepções é fundante a ideia de uma dialética entre essência e existência, substância e cultura, esperança e corpo. 
É nesse sentido que deveria ser compreendido no campo da CsR o termo sagrado (que, nessa ótica, equivaleria ao Incondicionado de Tillich), uma vez que revela uma qualidade da experiência humana. Essa qualidade, todavia, dada sua própria natureza, deve ser considerada em seu fundamento propriamente religioso, do qual derivam, todavia, outras tantas dimensões: sociedade, cultura, arte, política, crenças, etc.

Era isso, na verdade, o que se supunha, no começo dos anos 2000, entre os que esposavam a abordagem fenomenológica, no contexto dos embates brasileiros das CsR. Vejamos o que argumentavam, por exemplo, Vitória Peres de Oliveira e Antonio Gouvêa Mendonça em uma publicação, organizada por Luís Dreher, resultante também de um evento realizado em Juiz de Fora em 2001, "A essência manifesta". Ao passo que a primeira ressalta a questão do proprium religioso, Mendonça sublinha a manifestação dessa especificidade. Nas palavras de Oliveira:

Dentre as contribuições mais importantes da fenomenologia da religião poderse-ia citar a irredutibilidade e autonomia do fenômeno religioso. Esta concepção permitiu isolar o fenômeno religioso em si mesmo, dentro do que se passou a entender como o contexto tipicamente religioso, e não vê-lo como dependente e subordinado a outros contextos, quer filosóficos ou teológicos, e outras explicações, quer sociológicas, psicológicas, econômicas ou históricas.

O fenômeno religioso passa a ser observado em sua singularidade e particularidade, se busca o basicamente religioso. Como diz Mircea Eliade em seu Tratado de história das religiōes, só é possível compreender o significado de um fenômeno religioso se ele for estudado como algo religioso. Fazê-lo a partir de outro contexto, seja ele qual for, descuidando do seu contexto religioso original, onde está sua intenção primeira, destrói a possibilidade de captar o que este fenômeno tem de único e irredutível, o elemento sagrado (OLIVEIRA, 2003, p. 37).

Ora, trata-se, portanto, do esforço de compreensão de uma dimensão específica da vida humana. Do ponto de vista teórico, considera-se, em um primeiro momento, a religião em seu aspecto estruturante, no sentido de uma essência que perpassa a humanidade (ainda que o entendimento de tal essência varie conforme as preferências teóricas envolvidas); cujo resultado histórico-empírico são as religiões, religiosidades, espiritualidades, etc., em sua multiplicidade. A religião, nesse sentido, não existe sem essa materialidade. Isso, afinal, é que possibilita seu estudo sistemático. Era o que indicava também o argumento de Antonio Mendonça (2003, p. 95). 
Nem criptoteologia nem reducionismo sociológico: 369 contribuições para o debate epistemológico das Ciências da Religião no Brasil

Pode-se falar em ciência a partir do momento em que a experiência se organiza em religião - e que neste ato já perdeu sua inteireza em virtude das limitações da linguagem - e quando se expressa socialmente. Então, o objeto da ciência que trata das manifestações do sagrado só pode ter como objeto essas mesmas manifestações, isto é, a religião. O sagrado não iria além de um axioma a partir do qual se constrói um objeto de conhecimento, que é a religião.

Nessa perspectiva, portanto, os simpatizantes da Fenomenologia da Religião não estão, em momento algum, afirmando que não há uma dimensão derivada ou empírica, apenas que ela não é independente e que não pode ser considerada à parte de seu fundamento ontológico.

De outra forma, abdicar da Fenomenologia da Religião porque determinado autor "acredita que Deus existe", seria o equivalente a dispensar Marx e o marxismo porque "acreditavam" na sociedade sem classes, algo que parece também não passar de um sonho quasi religioso... Voltaremos adiante à questão da Fenomenologia da Religião.

No que se refere à acusação de "cripteologia" parece-nos que se Usarski explicasse melhor o que entende por "Teologia”, seria, para nós, mais fácil concordar com ele. Porém, essa acusação um tanto vaga pressupõe que "Teologia" seria o equivalente a "afirmações dogmáticas derivadas de uma fé positiva", e confunde "Teologia" com "Teologia cristã". Contudo, para muitos de nós, teólogos, tal compreensão soa bastante arcaica. Nesse caso, vale lembrar as palavras de Eduardo Gross: "teólogos/as são especialistas numa linguagem, são linguistas que estudam o dialeto de uma religião dada" (GROSS, 2001 p. 339). Desse modo, o teólogo lato sensu dedica-se à linguagem ou à gramática interna de qualquer religião que lhe interesse, não importando se esse teólogo tem uma relação de afinidade filial ou de crença para com aquela religião, enquanto o teólogo cristão (stricto sensu) dedica-se especificamente às linguagens do cristianismo. Gross, finalmente, propõe que o papel da Teologia no âmbito dos estudos de religião é o de clarificar terminologias das tradições, criticar discursos dogmáticos e reconhecer o caráter religioso das afirmações não religiosas. Tal roteiro desemboca em uma clara diferenciação: "teólogos são especialistas religiosos" e "cientistas da religião são especialistas em religião" (GROSS, 2001, p. 339), o que significa afirmar que muitos de nós não fazemos "criptoteologia", mas sim "Teologia”, de fato. Não uma Teologia engajada (seja ela "cristã", "afro" ou "islâmica"), mas uma Teologia compreensiva e interpretativa das linguagens dessas e de outras tradições, de suas expressões estéticas e de seus desdobramentos éticos ou, em termos tillichianos, uma "Teologia da cultura" aplicada ao fenômeno religioso. 


\section{O momento atual: a tradição revisitada?}

Recentemente, quando no Brasil a subárea de Teologia foi desmembrada da área de Filosofia junto à Capes e passou a identificar-se como área de Ciências da Religião e Teologia, esta estruturou sua árvore do conhecimento como composta das seguintes subáreas:

- Ciência da religião aplicada;

- Ciências da linguagem religiosa;

- Ciências empíricas da religião;

- Epistemologia das ciências da religião;

- História das teologias e religiões;

- Teologia fundamental-sistemática;

- Teologia prática;

- Tradições e escrituras sagradas.

Em termos estruturais, a nova área de Ciências da Religião foi pensada de modo equivalente às tradicionais áreas da Teologia: histórica, sistemática, bíblica e prática. Em modo esquemático, a equivalência é a seguinte:
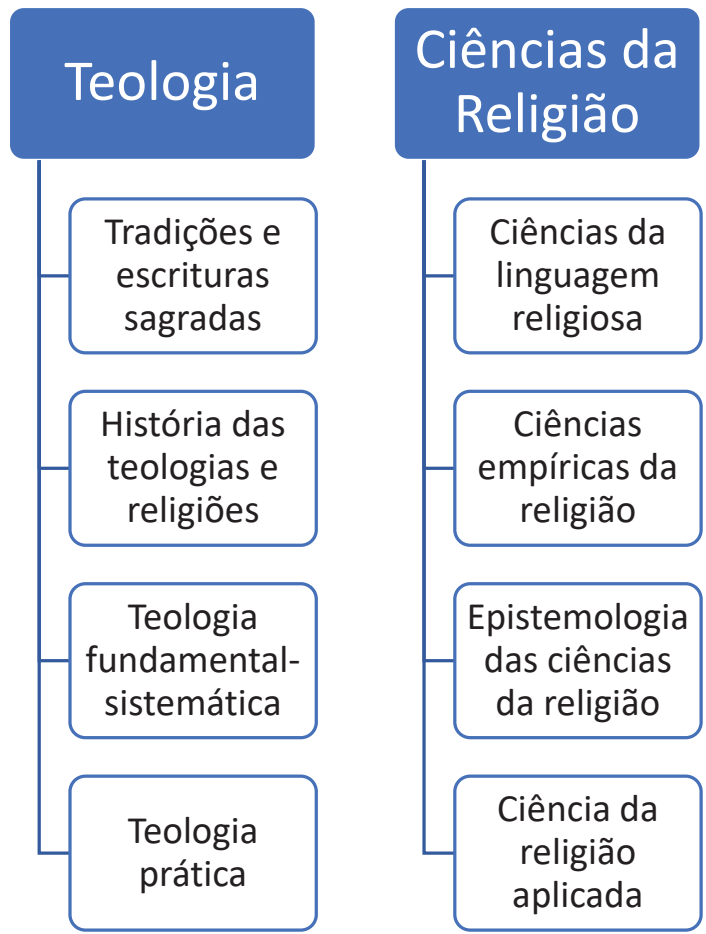

contribuições para o debate epistemológico das Ciências da Religião no Brasil

Assim posto, as Ciências da linguagem religiosa corresponderiam à tradicional área de Bíblia na Teologia; as Ciências empíricas da religião, ao que se chamava de Teologia histórica, dedicada tanto à história do dogma quanto à história da igreja; a área de Epistemologia das ciências da religião, equivaleria, por sua vez, à clássica área de Teologia sistemática; e por fim, como aconteceu na Teologia com sua área prática, a Ciência da religião aplicada surge como uma filha temporã. ${ }^{8}$

A reconfiguração da área indica, por si só, no nível teórico-político, um horizonte de superação da dicotomia entre essencialistas e funcionalistas, uma vez que assume uma paridade entre abordagens e interesses de modo orgânico na disciplina das CsR.

Outra questão a considerar é que, diferentemente de 20 anos atrás, tem-se hoje um número razoável de cursos de graduação na área. Em termos identitários, isso faz uma diferença substancial. Ora, ao final de um curso de graduação, o bacharel ou licenciado não será graduado em Sociologia da religião, Antropologia da religião, Filosofia da religião ou Teologia da religião, mas em Ciências da Religião, a saber, um profissional que deveria ter um conhecimento extensivo acerca do universo das religiões no Brasil e no mundo ao longo da história humana (momento histórico), bem como um saber substantivo acerca do significado da religião enquanto experiência de produção de sentido da humanidade (momento sistemático). Esses novos profissionais, tanto entenderão provavelmente mais de religião e das religiões que seus professores, que tiveram formação em outras áreas, quanto também poderão se posicionar de modo mais consciente e orgânico em relação às polêmicas teórico-políticas históricas das CsR. Afinal, pode-se manter a nomenclatura Ciências da Religião no plural, mas a identidade e a filiação profissional partirá sempre de um indivíduo, o cientista da religião, no singular.

Uma pergunta que pode ser interessante, a esta altura, é a seguinte: seria possível relacionar essa nova formulação da área na Capes com aquela tradicional estruturação da disciplina em dois momentos, um histórico e outro sistemático? A resposta é sim. E não só isso, mas essa relação pode ainda colaborar no entendimento e na identidade da área. Uma primeira possibilidade para pensar esquematicamente a questão poderia ser a seguinte:

O texto fundante, nesse sentido, é de Schleiermacher, publicado em 1830 como "Zur Darstellung des theologischen Studiums", com edição em inglês de 1850, "Brief outline of the study of theology". 


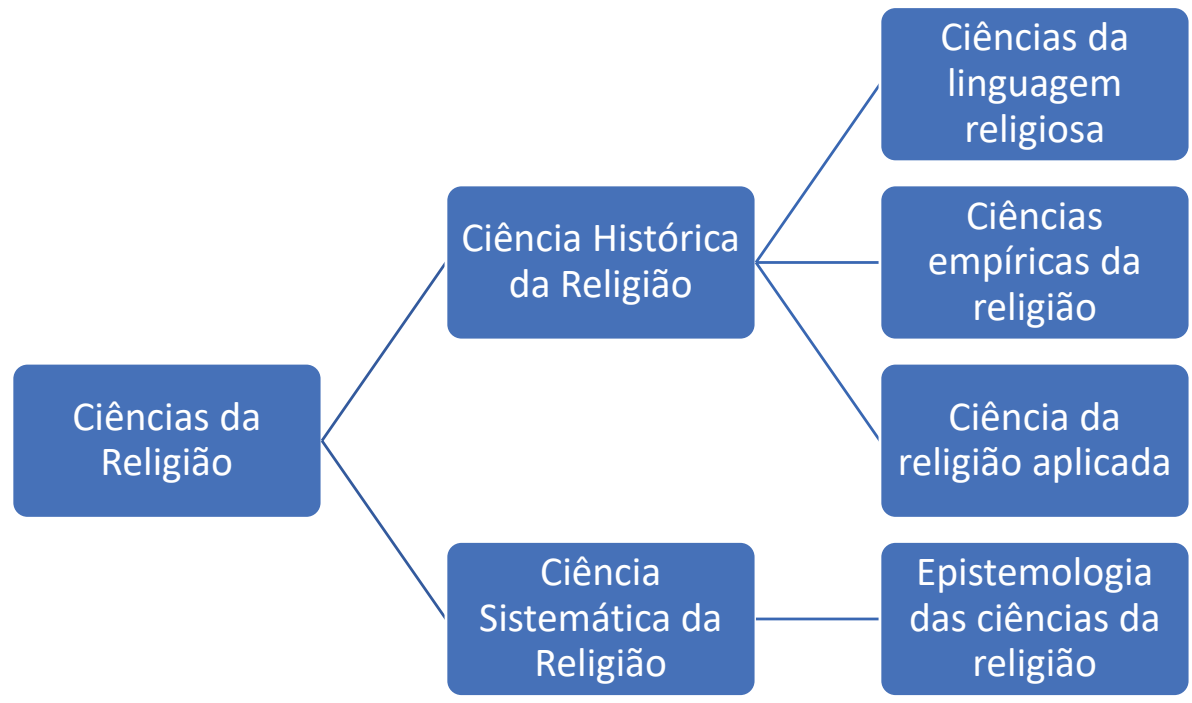

A Ciência Histórica da Religião dedica-se ao que Greschat (2005, p. 45ss) chama de "trabalho com o específico", abrigando o esforço de interpretação longitudinal. Ali estão presentes todas as atividades que constroem um corpus de material empírico: ritos, mitos, doutrinas, textos sagrados, textos sistemáticos, símbolos, imagens, correspondência, relatos, entrevistas, surveys, etc. As ciências empíricas da religião, assim como as da linguagem e a aplicada tem uma pertença estreita ao momento histórico. Tal perspectiva, inclusive, torna secundária, de certa forma, a diferença entre a área de linguagens e a área das ciências empíricas da religião, que se distanciam apenas metodologicamente. Ambas, em todo caso, devem ser pensadas a partir de uma aproximação hermenêutica da historicidade das religiões. Usinar a área de CR aplicada, permanece, por conseguinte, um horizonte e um desafio. Esforços consistentes têm sido feitos mormente no campo da educação e do Ensino Religioso. A fonte primária da Ciência da religião aplicada, seu ponto de partida e sua razão de ser, advém de demandas contextuais, determinadas, portanto, historicamente.

A Ciência Sistemática da Religião, por sua vez, dedicada ao que Greschat (2005, p. 105ss) chama de "trabalho com o geral", constitui o esforço de interpretação transversal. Estão nela em movimento os processos de teorização e de comparação entre as religiões. $\mathrm{O}$ olhar aqui pretende saber onde as religiões se tocam e se distanciam e o que elas revelam em conjunto 
Nem criptoteologia nem reducionismo sociológico: 373 contribuições para o debate epistemológico das Ciências da Religião no Brasil

sobre a vasta aventura humana. A Ciência Sistemática da Religião deve colorir o olhar de quem trabalha no momento específico. Ao passo que, por sua vez, a Ciência Histórica da Religião deve informar e dinamizar a reflexão feita no contexto do momento geral. Todo cientista da religião deveria, por isso, ter um pé em cada um dos dois momentos.

Para pensar a pertença da área de Epistemologia da Ciência da Religião ao momento sistemático, é preciso, todavia, deslocar um pouco a ideia de epistemologia como teoria geral do conhecimento, a fim de comportar uma teoria das Ciências da Religião, que diz respeito à construção e ao uso de instrumentos interpretativos da religião pelas CsR (ver p. ex. CRUZ, 2013, p. 38). Greschat (2005, p. 108), por exemplo, interpõe três instâncias ao momento sistemático: a teoria, tendo como exemplo o argumento de Otto em "O sagrado"; a comparação, indicando modos e possibilidades de comparação; e o fenômeno, onde discute especificamente questões centrais da Fenomenologia da Religião. Ao relacionar, nesse sentido, o momento sistemático com a área de Epistemologia das Ciências da Religião, dá-se um duplo movimento: de pensar, simultaneamente, uma teoria geral da religião e uma teoria do próprio fazer disciplinar. ${ }^{9}$

Ainda por outro lado, é preciso assumir que, conscientemente ou não, cada movimento acadêmico feito no campo do momento histórico, tem pressupostos epistemológicos forjados no momento sistemático. Ou seja, nas ciências das linguagens religiosas, nas empíricas da religião e nas aplicadas da religião, deve haver momentos sistemáticos subliminares. O contrário é também verdadeiro. Cada movimento feito no campo do momento sistemático, tem pressupostos empíricos forjados no momento histórico. Teoria e prática de pesquisa se retroalimentam constantemente. ${ }^{10}$ Há, na verdade, uma potência interdisciplinar interna às próprias CsR, uma vez que dados, teorias e métodos de determinada área informam as práticas das

9 Assim, por exemplo, a seção dedicada à epistemologia da ciência da religião no Compêndio de Ciência da Religião, organizado por Décio PASSOS e Frank USARSKI (2013), traz capítulos dedicados aos seguintes tópicos: Estatuto epistemológico da ciência da religião; História da ciência da religião; Metodologia em ciência da religião; Fenomenologia da religião; Filosofia da religião; Ciências naturais, religião e teologia; Religião e epistemologias pós-coloniais; Religião como forma de conhecimento; Religião e ética; Ciência da religião e teologia.

10 Cf. Jensen (2013, p. 178): “Teorias e evidências (dados) são mutuamente constitutivas. As generalizações são os resultados de reflexões teóricas sobre o que é considerado como evidência dentro de um dado espaço de definição teórico. Consequentemente, não existe qualquer generalização ou testes de hipóteses sem trabalhos comparativos” 
áreas vizinhas, e também que os pesquisadores assumem práticas teóricometodológicas diversas.

Nessa perspectiva, uma possibilidade de entendimento esquemático seria a que segue:

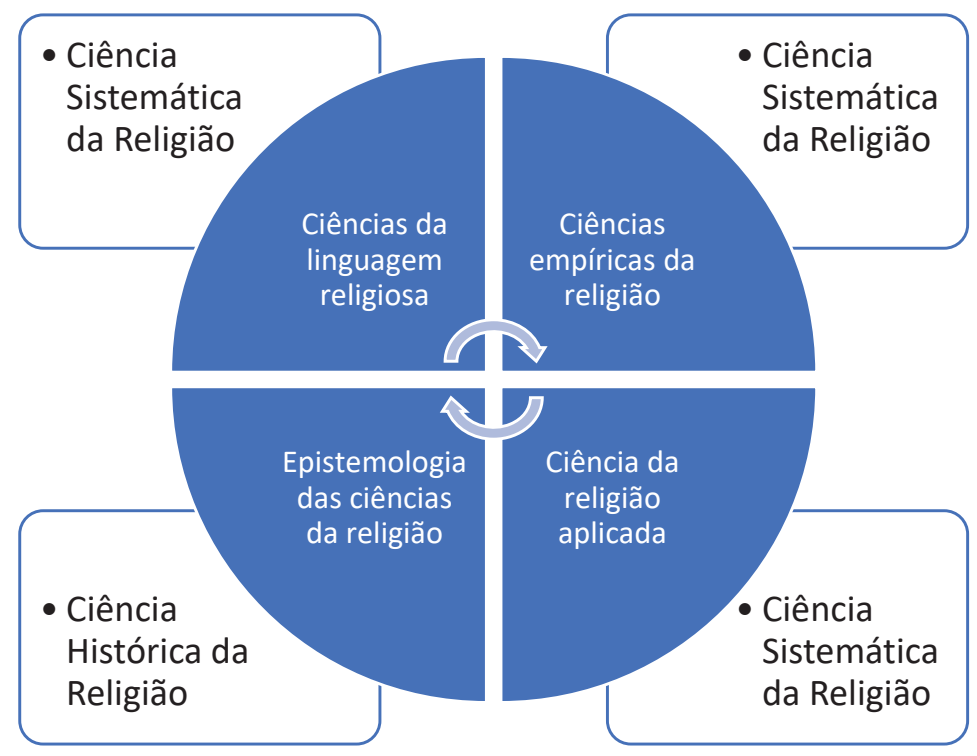

Cabe por fim perguntar: E quanto às demais disciplinas das humanidades? Como fica essa questão? Abdicaremos de autores consagrados com Durkheim e Weber, por exemplo? De todo o arsenal teóricometodológico construído ao longo de décadas no campo da teoria social da religião? Não! De modo algum! Nem das Ciências Sociais e nem de nada que se produziu acerca da religião em outras disciplinas. Não é necessário abdicar nem de Weber, nem de Durkheim, ou das pesquisas na área cognitiva, tanto quanto não o é em relação a Eliade, Otto, Tillich, Rubem Alves, etc.

O papel das demais disciplinas, nessa perspectiva, todavia, se altera. Elas não têm mais um quarto particular na casa, a não ser que seja um quarto de hóspedes. Cada disciplina constitui uma outra morada independente, com sua estrutura completa. Os cientistas da religião eventualmente as visitam, por vezes passam a noite ou uma temporada. Algumas podem estar na vizinhança, outras ainda em outra cidade ou país, o que demanda por parte do visitante aquilo que Renato Janine Ribeiro chamou de "poliglotismo 
Nem criptoteologia nem reducionismo sociológico: 375 contribuições para o debate epistemológico das Ciências da Religião no Brasil

cultural" (Apud MARCOVITCH, 2002, p. 234). Algumas podem parecer mais chiques, outras maiores, etc. Algumas abrigam famílias mais próximas e mais queridas, dependendo das histórias envolvidas. A relação, de qualquer, forma, será sempre igualitária entre estes universos-casas - que são relativamente autônomos, o que implica em reconhecer que são também relativamente interdependentes.

A relação das Ciências da Religião com as demais disciplinas constitui assim um processo interdisciplinar real que deve mover-se a partir de questões concretas relativas aos problemas de pesquisa e de produção de conhecimento. É nesse sentido que a expressão "disciplinas auxiliares" deve ser entendida. São campos do conhecimento diferentes e autônomos em relação às $\mathrm{CsR}$, aos quais, todavia, o cientista da religião recorre e deles se beneficia, dialogando em pé de igualdade. Um modelo esquemático para essa concepção seria o que segue:

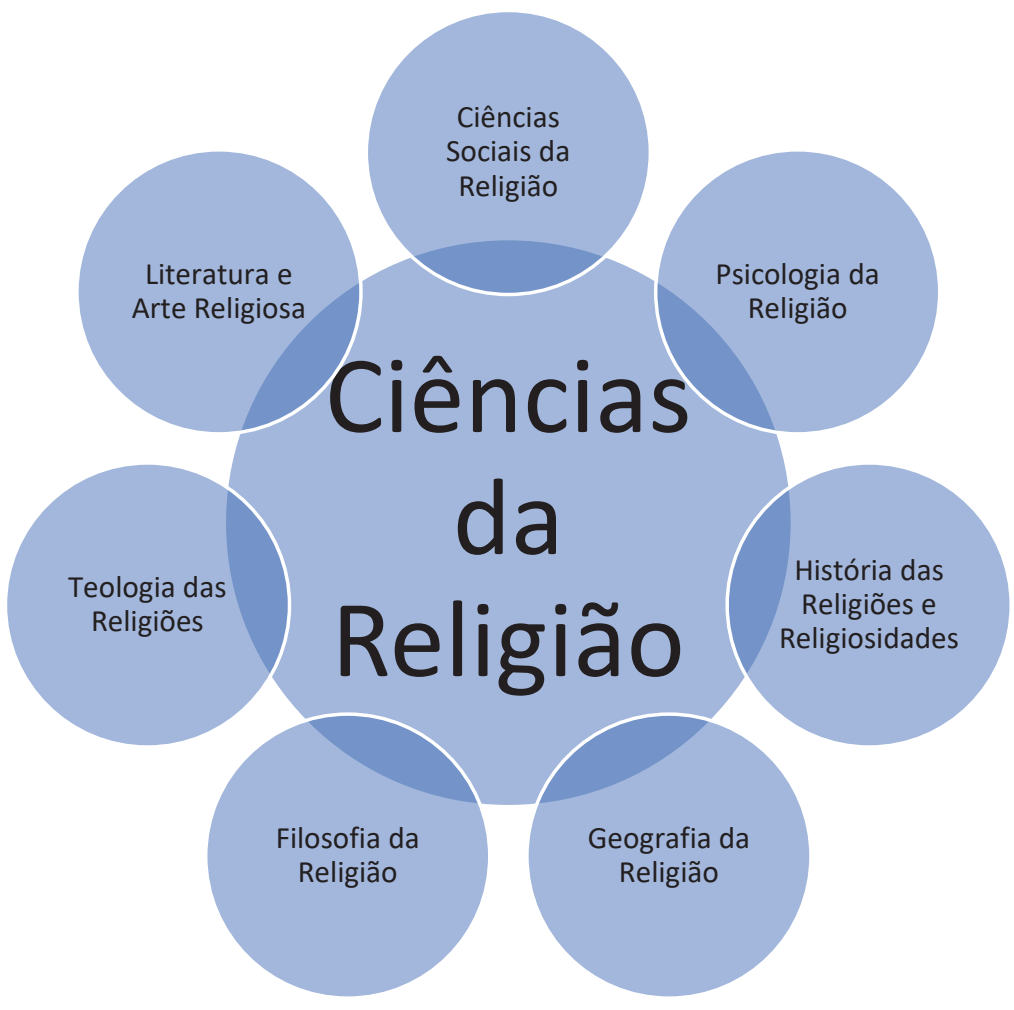




\section{E os gatos voltam a incomodar: da necessidade de uma atitude empática}

Voltemos, então, por fim, à questão da Fenomenologia da Religião, estruturante dos primeiros passos da disciplina. O que pensar sobre sua contundência, capaz de gerar debates tão calorosos até os dias atuais? Talvez seu recurso à experiência subjetiva de elaboração de sentidos seja de fato um elemento religioso a mover as tensões, afinal há crenças profundamente arraigadas de ambos os lados, entre essencialistas e desessencialistas.

É preciso admitir, primeiramente, que todo esse debate é permeado por boa dose de cientificismo, entremeado por uma disputa pela validação da verdade científica e da identidade da disciplina de Ciências da Religião. A religião, a vida, as pessoas, isso é outra coisa. Trata-se do objeto não reduzido ao discurso acadêmico, aquilo que excede as palavras e os conceitos por sua complexidade e dinâmica. A religião persiste como um enigma, como dizia Rubem Alves (1984 p. 33ss). Para compreendê-la, é preciso deixar-se envolver. É como na música: sem entrega, sem envolvimento, nada acontece, não há sentido. ${ }^{11}$ Demanda-se uma atitude silente, de escuta.

Ocorreu-nos, então, sugerir que a metáfora da casa com os moradores que a lotearam, poderia ser complementada pela incômoda presença de gatos que já ocupavam a casa muito antes da chegada dos atuais habitantes e do loteamento dos cômodos. Evidentemente, o bom leitor logo perceberá que, ao referir-nos a gatos, entramos no jogo da metáfora para dizer que as atitudes, linguagens e comportamentos religiosos (genericamente, "a religião") fazem parte da experiência humana muito antes do surgimento das ciências humanas e sociais e de sua compartimentalização na modernidade.

Há moradores que não gostam de gatos. Fazem de tudo para expulsálos. Acusam os gatos de serem transmissores de doenças, ou animais pegajosos e indomáveis. Gatos são também animais territoriais. Urinam nos cantos das paredes como a dizer: "esse território é meu". E de fato, quando um gato assume aquele lugar como seu, de direito, dificilmente se afasta dali. Podem ser enxotados pelos moradores, mas sempre reaparecem, mesmo que para dormir à noite no jardim, na varanda, ou do lado de fora à espreita da oportunidade de entrar na casa novamente.

\footnotetext{
11 Rubem Alves (1984, p. 38) gostava de usar a ideia de beleza para compreender também a religião: "É isso que encontramos na experiência estética. O belo não é nem o objeto, em si, e nem o sujeito em si, mas antes a relação que os unifica num êxtase místico”.
} 
Nem criptoteologia nem reducionismo sociológico: 377 contribuições para o debate epistemológico das Ciências da Religião no Brasil

Há até quem sugira levar os gatos para bem longe... de preferência para algum país nórdico, como a Dinamarca, Suécia, Noruega, ou mesmo a gelada ilha da Islândia, porque por lá, aparentemente a população de gatos diminuiu e não há futuro para eles. Mas é difícil garantir que enviar os gatos para a Dinamarca seja o melhor caminho. Na semana seguinte eles estarão de volta. É lamentável que haja moradores que até mesmo envenenem os gatos para exterminá-los de vez. Mesmo os gatos envenenados e mortos deixarão ali os cheiros de sua anterior presença e atrairão novos gatos.... Talvez o problema seja pensarmos que a casa é dos moradores atuais. Ela é dos gatos. Os moradores são apenas visitantes. Se tentarem castrar os gatos, é ainda pior. Aí é que realmente não vão embora. Talvez começar a pensar o que temos em comum com os gatos seja uma postura melhor.

É o que nos leva novamente à controversa Fenomenologia da Religião. Deve-se pensá-la mais como uma atitude que como um método ou uma disciplina. A ideia de "empatia estruturada" auxilia, nesse sentido. Ninian Smart (1995, p. 14-15) a propôs, sugerindo que se deixe de lado a expressão "Fenomenologia da Religião", o que evitaria imiscuir o debate nos meandros da Fenomenologia husserliana, que influenciou parte mas não toda a Fenomenologia da Religião.

[...] o termo 'fenomenologia' (o estudo do que aparece) tem sido usado de uma maneira menos técnica pelos historiadores da religião. O que emprestam de Husserl é a ideia de que o mundo dos fieis pode ser descrito sem introduzir as suposições e o ponto de vista do pesquisador. Por várias razões penso que é melhor não usar o termo 'fenomenologia', mas a expressão 'empatia estruturada'. Empatia significa literalmente 'sentir em'; é tentar sentir o que está lá dentro de uma pessoa ou de um grupo de pessoas. Não é a mesma coisa que simpatia, 'sentir com' [...] porque simpatia significa concordar com o outro. Mesmo que eu não concorde com uma outra pessoa, ainda posso, mesmo assim, ter empatia. [...] a empatia nos ajuda a entender melhor os fatos - porque os fatos incluem os modos que a pessoa sente e pensa o mundo.

Por isso, também, a empatia precisa ser estruturada. Devemos compreender a estrutura de um outro mundo; e, de modo geral, tentar entender as estruturas de crença presentes na mente do fiel (SMART, 1995, p. 14-15). ${ }^{12}$

12 " $[. .$.$] the word phenomenology (the study of what appears) has been used in a less$ technical way by historians of religion. What they borrow from Husserl is the idea that the believer's world can be described without introducing the assumptions and slant of the investigator. For various reasons I think it is best not to use the word 'phenomenology', but rather the phrase 'structured empathy'. 
Dessa atitude, portanto, pode advir uma postura de escuta e de compreensão, que busca pôr entre parênteses as crenças do pesquisador (epoche) a favor da interpretação do universo pesquisado, entendido como estruturado a seu próprio modo. Nesse sentido, ambos momentos das CsR, o histórico e o sistemático, estariam perspectivados e impulsionados pela atitude fenomenológica, a empatia estruturada de Smart.

A persistência do fenômeno religioso na sociedade é, afinal, inegável. No Brasil, as festas populares do catolicismo, as diversas formas de neopentecostalismo, as festas para Iemanjá, a lavagem da escadaria do Senhor do Bonfim, O círio de Nazaré, as romarias a Aparecida e as muitas romarias menores que acontecem no interior e que a mídia não divulga, os Novos Movimentos Religiosos de classe média, seja através das redes de TV católicas, ou formas de espiritualidade hindu (há uma onda de ioga em muitos centros urbanos brasileiros) .... tudo isso parece não estar sendo visto da janela lateral do quarto de dormir de muitos pesquisadores.... aparentemente a prática de CsR em alguns casos contenta-se com os gabinetes e escritórios e olha com desdém essas manifestações como se fossem mero "folclore", sem muita importância, miados de gatos famintos e às portas da morte por inanição.

Mesmo quando se fala em países da Europa ou do Oriente, esquecese que a persistências das atitudes e comportamentos religiosos ali é muito forte. Silvério Pessoa (2013) fez, há poucos anos, uma pesquisa no interior da moderna e laica França. Dois meses lá foram suficientes para retornar com uma invejável quantidade de fotografias, vídeos e áudios sobre a religiosidade popular no interior da França e nas periferias de Paris. Pôde verificar que o catolicismo popular é muito mais forte do que se imagina na França. Igrejas lotadas em dias de domingo, ou em festas religiosas. Santuários semelhantes aos do Nordeste, dedicados a "santos populares". Há efervescência religiosa nas periferias de Paris, no catolicismo, mas principalmente em manifestações islâmicas.

Empathy literally means 'filling in'; it is getting at the feel of what is inside another person or group of persons. It is not quite the same as sympathy, 'feeling with' (pathy sym rather than pathy em), for sympathy means I agree with the other. Even if I do not agree with the other person, however, I can still have empathy. [...] empathy helps us to better grasp the facts - for the facts include the way she feels and thinks about the world.

This is why, too, the empathy needs to be structured. We have to comprehend the structure from another's world; and in general, we have to try to understand the structures of believe inside the head of the believer" (SMART, 1995, p. 14-15). 
Nem criptoteologia nem reducionismo sociológico: 379 contribuições para o debate epistemológico das Ciências da Religião no Brasil

Talvez também não se tenha dado a atenção devida ao fato de que, em 2019, no Japão, por ocasião da posse do novo Imperador, o governo japonês decretou nove dias de feriado nacional. Essa tradição não é meramente folclórica, mas extremamente vinculada a referenciais do xintoísmo. Tempo de caos que precede à ordem. Durante nove dias nada funcionou no Japão, além de serviços emergenciais. Até mesmo a bolsa de valores de Tóquio fechou. Ora, convenhamos... que poder é esse que em pleno século XXI é capaz de fechar a bolsa de valores de Tóquio? Os gatos japoneses são muito mais poderosos do que se imagina.

A religião tem essa estranha recorrência que pode ser exemplificada pela antiga canção de Raimundo Fagner: "quando a gente tenta, de toda maneira, dele se guardar... sentimento ilhado, morto, amordaçado, volta a incomodar...."

Sabe-se que há quem se utilize das CsR para militância, pró ou contra as religiões. Há os que, não vendo nada de positivo na religião, insinuam: “está vendo? Religião não serve pra nada... é ópio... alienação"... "está vendo como os gatos são nocivos?" Há também os que gostam dos gatos e os defendem às vezes até mesmo humanizando-os, e se esquecem que são de outra espécie, de outra sensibilidade, e que sua natureza é outra.

Daí a importância de revisitar sempre novamente a palestra de Max Weber (2013) sobre "a ciência como vocação", especialmente as páginas finais. Cientistas não podem ser militantes. Não defendem, nem condenam. Apenas tentam compreender as motivações, a experiência, as linguagens, etc... e de modo empático. Enquanto isso, os gatos permanecem na casa, ou rondando a casa. Muitas vezes durante o dia são silenciosos; dormem bastante.... mas há noites em que estão inquietos, principalmente nas madrugadas de cio.

\section{Considerações para debate}

Enfim, o pesquisador das CsR experimenta hoje a hegemonia da compreensão da área no plural, naquele sentido de uma casa com muitas moradas. As questões identitárias e teórico-metodológicas da área, todavia, continuam a preocupar e a motivar eventos acadêmicos. Novos desafios surgem, como as licenciaturas em CsR para o Ensino Religioso; assim como o novo campo da ciência da religião aplicada, e tudo o que a envolve: turismo religioso, movimentos migratórios, religião e direito civis etc. Pode parecer um tanto onírica a tentativa aqui apresentada, ante o peso da compreensão hegemônica estabelecida no Brasil. Esta proposta vem, mesmo assim, bem 
acompanhada pelos propositores iniciais da disciplina, os "pais fundadores" das CsR, e constitui, ao menos, um horizonte a mais aberto ao diálogo e à crítica.

\section{Referências}

ALVES, Rubem. O enigma da religião. Campinas: Papirus, 1984.

CAMURÇA, Marcelo Ayres. Ciência da religião, ciências da religião, ciências das religiões? Observações de um antropólogo a partir da experiência no corpo docente de um programa de pós-graduação da área. In: TEIXEIRA, Faustino (org.). A(s) ciência(s) da religião no Brasil, a afirmação de uma área acadêmica. São Paulo: Paulinas, 2001, p. 197-232.

CRUZ, Eduardo R. Estatuto epistemológico da ciência da religião. In: PASSOS, João Décio; USARSKI, Frank (orgs.). Compêndio de ciência da religião. São Paulo: Paulus, Paulinas, 2013, p. 37-49.

ELIADE, Mircea. Crise e renovação. In: ELIADE, Mircea. Origens: história e sentido na religião. Lisboa: Edições 70, 1989.

O sagrado e o profano. São Paulo: Martins Fontes, 1992.

GRESCHAT, Hans-Jürgen. O que é ciência da religião? São Paulo: Paulinas, 2005.

GROSS, Eduardo. A ciência da religião no Brasil: teses sobre sua constituição e seus desafios. In: OLIVEIRA, Kathlen Luana de; REBLIN, Iuri Andréas; SCHAPER, Valério Guilherme; GROSS, Eduardo; WESTHELLE, Vítor (Organizadores). Religião, política, poder e cultura na América Latina. São Leopoldo: Escola Superior de Teologia, 2012, p. 13-26.

Considerações sobre a teologia entre os estudos da religião. In: TEIXEIRA, Faustino (org.). A(s) ciência(s) da religião no Brasil, a afirmação de uma área acadêmica. São Paulo: Paulinas, 2001, p. 323-346.

MARCOVITCH, Jacques. Os desafios da área de Humanidades no Brasil e no mundo. Estudos avançados, São Paulo, v. 16, n. 46, p. 223-243, Dez. 2002. Disponível em: <http://www.scielo.br/scielo.php?script=sci_arttext\&pid=S0103-40142002000300017\&lng= en\&nrm=iso $>$ Acesso em 15 de Fev. de 2021.

MENDONÇA, Antonio Gouvêa. A persistência do método fenomenológico na sociologia da religião: uma aproximação sob o prisma da essência e da forma. In: DREHER, Luís (org.). A essência manifesta, a fenomenologia nos estudos interdisciplinares da religião. Juiz de Fora: Editora UFJF, 2003, p. 77-102.

OLIVEIRA, Vitória Peres de. A fenomenologia da religião: temas e questões sob debate. In: DREHER, Luís (org.). A essência manifesta, a fenomenologia nos estudos interdisciplinares da religião. Juiz de Fora: Editora UFJF, 2003, p. 35-58.

OTTO, Rudolf. O sagrado. São Leopoldo: Sinodal/ EST; Petrópolis: Vozes, 2007.

PESSOA, Silvério Leal. Expressões da religiosidade popular, sul da França (cultura occitana) e Pernambuco em diálogos contextuais. Dissertação (mestrado em Ciências da religião), UNICAP, Recife, 2013. 
Nem criptoteologia nem reducionismo sociológico: 381 contribuições para o debate epistemológico das Ciências da Religião no Brasil

PIRES, Frederico. Aspectos históricos e epistemológicos da Ciência da Religião no Brasil. Numen: revista de estudos e pesquisa da religião, Juiz de Fora, v. 21, n. 2, jul./dez. 2018, p. 232-291. Disponível em: <https://periodicos.ufjf.br/index.php/numen/article/view/22159> Acesso em: 02/03/2021.

Fenomenologia da religião como essencialista e criptoteologia: reconsiderações críticas. Horizonte: Revista de Estudos de Teologia e Ciências da Religião (Online), v. 17, 2019, p. 801-831. Disponível em: <http://periodicos.pucminas.br/index.php/ horizonte/article/view/20388/1646> Acesso em: 02/03/2021.

SCHLEIERMACHER, Friedrich. Brief outline of the study of theology. Edinburgh: T\&T Clark, 1850.

SMART, Ninian. Worldviews, crosscultural explorations of human beliefs. $2^{\mathrm{a}}$ ed. Englewood Cliffs, New Jersey: Prentice Hall, 1995.

TEIXEIRA, Faustino. Apresentação. In: TEIXEIRA, Faustino (org.). A(s) ciência(s) da religião no Brasil, a afirmação de uma área acadêmica. São Paulo: Paulinas, 2001, p. 3-9.

TILLICH, Paul. A era protestante. São Paulo: Ciências da religião, 1992.

Dinâmica da fé. $5^{\text {a }}$ ed. São Leopoldo: IEPG/Sinodal, 1996.

USARSKI, Frank. Constituintes da Ciência da Religião: cinco ensaios em prol de uma disciplina autônoma. São Paulo: Paulinas, 2006.

Perfil paradigmático da Ciência da Religião na Alemanha. In: TEIXEIRA,

Faustino (org.). A(s) ciência(s) da religião no Brasil, a afirmação de uma área acadêmica.

São Paulo: Paulinas, 2001, p. 67-102.

WACH, Joachim. Introduction to the history of religions. New York: Macmillan Publíshíng Company, 1988.

WEBER, Max. Ciência e política, duas vocações. 20. ed. São Paulo: Cultrix, 2013.

Submetido em: 28-6-2021

Aceito em: 11-10-2021 